УДК 621.396

Свген Олександрович Степаненко (кандидат технічних наук) ${ }^{1}$

Вячеслав Олексійович Думітраш ${ }^{2}$

Ольга Вячеславівна Думітраш ${ }^{3}$

Віталій Валерійович Кокошинський ${ }^{2}$

${ }^{1}$ Військова частина А0106, Київ, Украйна

${ }^{2}$ Військовий інститут телекомунікацій та інформатизації імені Героӥв Крут, Київ, Украӥна

${ }^{3}$ Військова частина А0415, Семиполки, Украӥна

\title{
ПЕРСПЕКТИВИ РОЗВИТКУ ТРОПОСФЕРНОГО ЗВ'ЯЗКУ В ІНФОРМАЦІЙНО-ТЕЛЕКОМУНІКАЦІЙНИХ СИСТЕМАХ СПЕЦІАЛЬНОГО ПРИЗНАЧЕННЯ
}

Сучасні військові конфлікти змінили загальний підхід до ведення бойових дій. Раніше війни розвивалися шляхом наростання масштабності (масовості) при безпосередньому контакті військ (сил), то сучасні війни ведуться за принципом зменшенням людського ресурсу при збільшенні використання високоінтелектуальної зброї на значних відстанях. На сьогоднішній день иироке застосування високоточної зброї, засобів вогневого ураження в поєднанні з засобами розвідки, диверсійнорозвідувальних груп, незаконних збройних формувань, засобів радіоелектронного придушення, суттєво впливає на функиіонування системи військового зв'язку.

Дана тендениія в майбутньому буде тільки посилюватись, щуо створюватиме загрози функиіонування системи управління.

У війні майбутнього, кожна Держава, ставить своїм завданням адекватно і своєчасно виявити ключові ризики, напрямок технологічного розвитку, та зрозуміти, як він може вплинути на потенціал можливого майбутнього військового конфлікту.

У найближчому майбутньому основу перспективної інформаційно-телекомунікаційної системи ЗС Украӥни повинна становити об'єднана автоматизована цифрова система зв'язку, яка повинна включати космічний, повітряний, наземний (польовий $i$ стаціонарний) $i$ морський компонент, автоматизовану систему управління зв'язком і систему інформаційної безпеки та повинна сприяти більш тісному зближенню (взаємної інтеграції) систем управління військами та зброєю в єдину інформаційно-розвідувально-вогневу (ударну) просторово розподілену систему, ключовими елементами якої є розвідувально-ударні комплекси.

У зв'язку з ичим виникла необхідність коригування підходів до визначення основних напрямків розвитку засобів і комплексів тропосферного зв'язку як складової інформаційно-телекомунікаційної системи ЗС Украӥни.

У статті викладені пропозищіi щ⿻одо перспектив розвитку засобів тропосферного зв'язку в інтересах Збройних Сил Украӥни.

Ключові слова: тропосферний зв'язок; електромагнітна сумісність; фізико-географічні умови.

\section{Вступ}

Постановка проблеми. Досвід бойових дій у ході проведення ООС (АТО) показав ряд проблемних питань 3 організації зв'язку в тактичній (оперативній) ланці управління. Серед основних факторів, що негативно вплинули на організацію зв’язку, слід зазначити наступні: недоцільність побудови багатоінтервальних радіорелейних ліній зв'язку через складнощі при організації охорони та оборони радіорелейних станцій на територіях, що не контролюються військовими формуваннями; відсутність національної супутникової системи зв'язку та необхідність оренди трафіку у цивільних операторів зв'язку; недостатня кількість апаратних (станцій) зв'язку та відповідного особового складу в штаті військових частин для виконання поставлених завдань у складі батальйонних (ротних) тактичних груп. В той же час перед телекомунікаційними системами та мережами спеціального призначення постають сучасні вимоги системи управління військами (силами) щодо забезпечення всіма видами телекомунікаційних послуг 3 визначеною якістю. Це, в свою чергу, вимагає вирішити завдання щодо забезпечення високої пропускної спроможності транспортних телекомунікаційних систем спеціального призначення. В таких умовах, для забезпечення зв'язку на перший план виходять засоби, які дозволяють швидко організувати інформаційні напрямки між пунктами управління. Такими $є$ супутникові та тропосферні станції зв'язку. Однак супутникові засоби мають недоліки: залежність від іноземного оператора, висока вартість оренди послуг, тощо. Тому, найбільш актуальними для застосування у 
Збройних Силах України та інших військових формуваннях для побудови цифрових телекомунікаційних систем та мереж є станції та комплекси тропосферного зв'язку. Серед основних переваг застосування тропосферного зв'язку слід зазначити наступні: відсутність залежності від рельєфу та інших факторів місцевості; забезпечення зв'язку на велику дальність (до 200 км та більше); невеликий час на розгортання тропосферних ліній зв'язку; висока мобільність станцій на автомобільній базі, можливість встановлення обладнання на бронебазу.

Аналіз останніх досліджень і публікацій. Стан, проблемні питання та напрями подальшого розвитку вітчизняних тропосферних систем зв'язку було досліджено в роботах [1,2], автори яких розглядають технічні аспекти роботи тропосферних станцій в сучасних умовах та пропонують шляхи їх модернізації.

В роботах іноземних фахівців [3-5] автори висвітлюють окремі варіанти розвитку тропосферного зв'язку шляхом покращення їх технічних характеристик, зокрема в [3] будуються оптимізаційні моделі роботи тропосферних станцій, в роботі [4] автор проводить дослідження моделі прогнозування втрат передачі тропорозсіювання, а в роботі [5] розраховується пропускна здатність когерентності тропорозсіювання за допомогою частотної кореляційної функції.
Мета статті полягає у визначенні перспектив розвитку тропосферного зв'язку в інтересах застосування сил оборони держави.

\section{Виклад основного матеріалу дослідження}

Станції тропосферного зв'язку можуть застосовуватися в режимах прямого або загоризонтного зв'язку (рис.1):

в стратегічний ланці управління - в польовій транспортній мережі зв'язку для розгортання стаціонарних i мобільних магістральних ліній зв'язку, спільно $з$ радіорелейними і кабельними лініями, а також ліній прив'язки до вузлів зв'язку операторів телекомунікацій України, вузлів зв'язку сил сектора безпеки і оборони;

в оперативно-тактичний ланці управління - для організації прямих зав'язків, для прив'язки ІТВ (В3) пунктів управління до ОВ3, для розгортання окремих одно або двоінтервальних ліній [1-3];

в тактичній ланці управління - для розгортання одноінтервальних ліній між ITB (B3) пунктів управління, елементів бойового порядку своїх i взаємодіючих військ, а також організації ліній прив'язки до транспортної мережі спеціального призначення (ТМСП) і операторів телекомунікацій України;

в частинах і підрозділах видів збройних сил для розгортання окремих одно або двоінтервальних ліній між ITB (В3) пунктів управління і системами озброєнь (об'єктами управління).

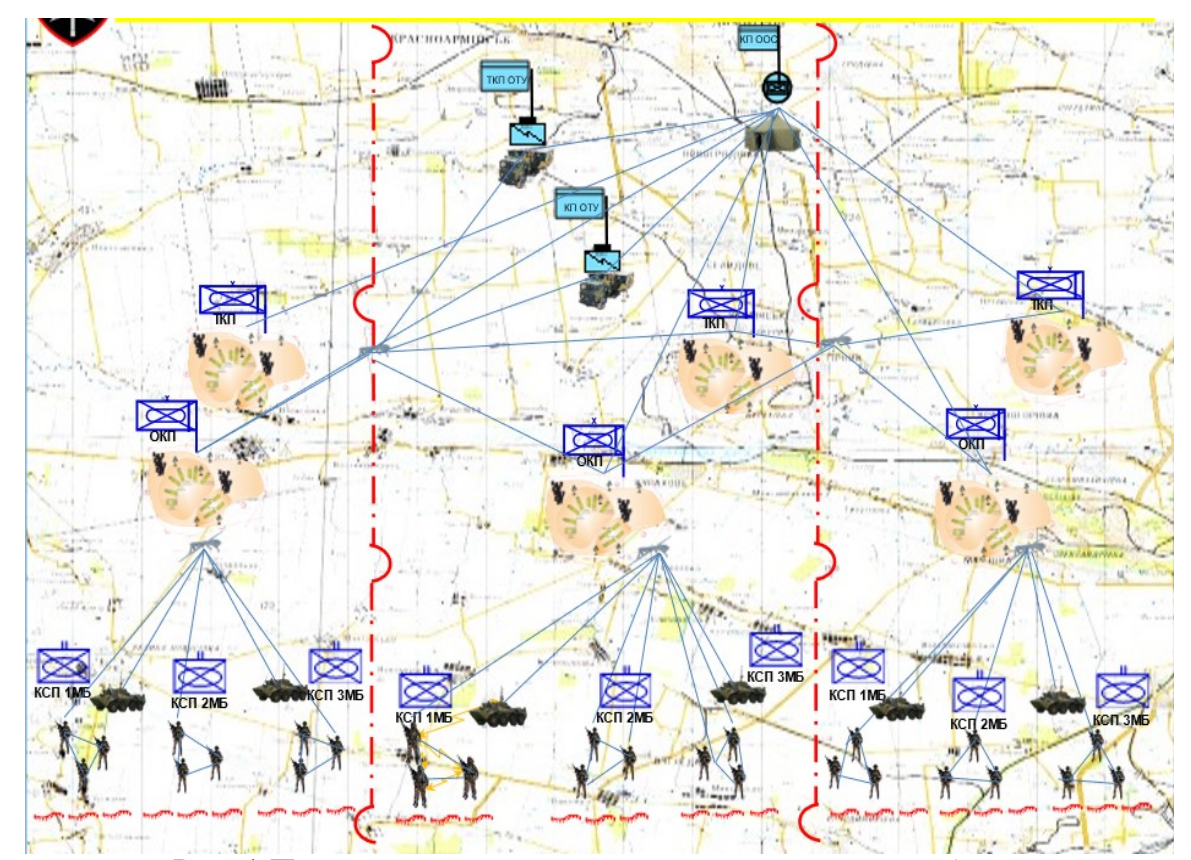

Рис. 1 Перспективна модель розгортання системи зв'язку

Не виключається можливість розгортання самостійних багато і одноінтервальних ліній зв'язку, у тому числі для поєднання 3 радіорелейними і кабельними лініями, а також для прив'язки ITB (B3) пунктів упралвння до транспортної мережі ЗС України.

Станції тропосферного зв'язку, що розгортаються в системі зв'язку усіх ланок управління, будуть піддаватися впливу дестабілізуючих факторів [3-5].

Дестабілізуючі фактори, що впливають на експлуатацію тропосферних станцій можна класифікувати за наступними категоріями:

за місцем виникнення - зовнішні та внутрішні;

за фізичною природою виділяють - звичайна зброя, високоточна зброя, радіоелектронні засоби боротьби противника, технічні та експлуатаційні відмови, переміщення об'єктів управління, 
фізично-географічні умови та ін.;

за ступенем визначеності - детерміновані (наприклад, планова перебудова режимів роботи), імовірнісні 3 відомими законами розподілу (технічні відмови), імовірнісні 3 невідомими законами розподілу, що невизначені (час нанесення масового вогневого удару);

за тривалістю впливу - постійнодіючі (ненадійність апаратури), періодичні (вогневе ураження), разові;

за інтенсивністю впливу - слабої, середньої та сильної інтенсивності;

за проявом - навмисні і випадкові.

Відповідно до характеру впливу зазначених факторів тропосферний зв'язок відзначається живучістю, завадостійкістю та надійністю.

Вплив дестабілізуючих факторів на станції тропосферного зв'язку поділяється на вплив внутрішніх і зовнішніх дестабілізуючих факторів.

Під внутрішніми дестабілізуючими факторами по відношенню до обладнання тропосферних станцій розуміються дестабілізуючі фактори, джерела впливу яких перебувають всередині засобів та $\epsilon$ достатньо інформації про характеристики їх впливу, що дозволяє приймати ефективні рішення по їх локалізації та проведенню відповідних профілактичних і ремонтновідновлювальних заходів на всіх етапах, від розробки і виробництва засобів до планування їх експлуатації.

Найбільш поширеними джерелами внутрішніх дестабілізуючих факторів $є$ :

старіння радіоелементів (зміна 3 часом їх характеристик);

якість електричних з'єднань;

порушення електромагнітної сумісності (порушення екранування, заземлення, фільтрації) i, внаслідок цього, погіршення стійкості обладнання до впливу електромагнітного випромінювання [2];

перебої в електропостачанні.

Внутрішні дестабілізуючі фактори пов'язані зі специфікою застосування комплексів і засобів зв’язку, їх завантаженістю і умовами експлуатації, що призводить до поступового фізичного зносу елементів i вузлів системи. Фізичний знос обумовлений багатьма факторами, серед яких не останнє місце займає старіння (зношення) матеріалів несучих конструкцій, яка з'являється при тривалих термінах експлуатації.

Під зовнішніми дестабілізуючими факторами (ЗДФ) по відношенню до телекомунікаційної мережі розуміються такі дестабілізуючі фактори, джерела яких розташовані поза даною мережею.

Джерелами ЗДФ є фізичні об’єкти, які в сукупності 3 системами або подіями, що визначають моменти i характер природи виникнення, виділяють енергію для формування дестабілізуючих факторів.

Залежно від характеру впливу на елементи телекомунікаційної мережі ЗДФ поділяються на класи:

механічні (сейсмічний удар, ударна хвиля, інші механічні фактори);

електромагнітні

високочастотне випромінювання, електромагнітний імпульс);

іонізуючі (альфа-випромінювання, бетавипромінювання, гамма-випромінювання, нейтронне випромінювання);

термічні (світлове випромінювання, пошкодження відкритим вогнем).

Джерела ЗДФ за ознакою приналежності до природи виникнення поділяють на:

об’єктивні (природні) - моменти виникнення і спрямованості виділення енергії, які носять випадковий характер, є джерелами ненавмисних дестабілізуючих факторів (землетрус, розряд блискавки, радіоактивне зараження місцевості, техногенні катастрофи, лінія електропередачі в аварійному режимі, радіолокаційні станції та ін.).

суб'єктивні (штучні) - моменти виникнення і спрямованість виділення енергії мають на меті порушення працездатності ТСС3, та являють собою джерела навмисних дестабілізуючих факторів (всі види сучасної зброї, терористичні акти, навмисні електромагнітні впливи, в тому числі здійснювані кондуктивним шляхом (безпосереднє підключення до кабелів електрозв'язку спеціальних технічних засобів, що генерують навмисні перешкоди).

До джерел ЗДФ локальної дії відносяться джерела дестабілізуючих факторів, що діють протягом невеликих проміжків часу i здатні привести до порушення працездатності хоча б одного елемента ТСС3 (порушення працездатності групи просторово рознесених елементів ліній тропосферного зв'язку) [3-5].

Найбільшу загрозу для стійкості роботи засобів тропосферного зв'язку представляють джерела просторової дії або численні джерела локальної дії, збуджені протягом невеликих проміжків часу в різних місцях на великому просторі.

Особливий вплив на умови застосування станцій тропосферного зв'язку надають фізикогеографічні умови як 3 точки зору тактики застосування засобів тропосферного зв'язку, так і з точки зору фізики процесів забезпечення дальності роботи лінії зв'язку.

Під фізико-географічними умовами слід розуміти поєднання:

географічного положення (географічні координати крайніх точок);

рельєфу місцевості;

кліматичних умов (атмосферні опади, ї кількість, інтенсивність, розподіл, температура i вологість повітря, радіаційний пояс);

геологічної будови земної кори;

характеру грунтового і рослинного покрову.

Властивості місцевості, що здійснюють вплив на основні сторони бойової діяльності військ, прийнято називати тактичними властивостями місцевості. Оцінка місцевості при плануванні бою або операції включає вивчення наступних iï основних тактичних властивостей:

умов прохідності для бойової техніки і транспорту;

умов маскування, інженерного обладнання місцевості;

умов спостереження, орієнтування та ведення вогню; 
умов захисту військ від впливу ядерної i звичайної зброї та ін.

Вплив місцевості на хід бойових дій визначається на основі бойового завдання, 3 урахуванням складу військ, пори року і доби, а також метеорологічних умов i характеру дій противника.

Типи місцевості характеризуються переважаючими формами рельєфу i грунтоворослинним покровом.

За характером рельєфу місцевість поділяється на рівнинну, горбисту і гірську.

За характером грунтово-рослинного покрову розрізняють пустельну, степову, лісову (лісисту), болотисту, лісисто-болотисту місцевість.

Рівнинна місцевість характеризується відсутністю різко виражених нерівностей земної поверхні, невеликими відносними перевищеннями (до 25 м) і порівняно малою крутістю схилів (до $2^{\circ}$ ).

Рівнинна місцевість більш сприятлива для організації і ведення наступу і менш сприятлива для оборони. Відсутність значних відносних перевищень забезпечує достатню дальність видимості у всіх напрямках і ефективність радіо-, радіорелейного та тропосферного зв'язку. Разом 3 тим рівнина ускладнює організацію маскування, але захисні властивості мінімальні.

Горбиста місцевість характеризується хвилястим характером земної поверхні, що утворює нерівності 3 абсолютними висотами до 500 м, відносними перевищеннями 25-200 м і переважною крутістю схилів $23^{\circ}$. Горбиста місцевість допускає бойові дії всіх родів військ, забезпечує приховане від наземного спостереження противника пересування, розгортання і здійснення маневру підрозділами. В цілому сприятлива як для наступу, так i для оборони.

Гірська місцевість характеризується різкою пересіченістю рельєфу, наявністю важкодоступних ділянок, малорозвиненою мережею доріг, обмеженою кількістю населених пунктів, бурхливою течією річок з різкими коливаннями рівня води, різноманітністю кліматичних умов та переважно кам'янистих грунтів. Гірську місцевість поділяють на низькогірну, середньогірну i високогірну місцевість. Бойові дії в гірській місцевості розглядаються як дії в особливих умовах.

Низькогірна місцевість характеризується висотами над рівнем моря 500-1000 м, відносними перевищеннями 200-500 м і переважною крутістю схилів 5-10. У порівнянні 3 іншими видами гірської місцевості вона слабко розчленована, звичайно добре обжита і має порівняно розвинену дорожню мережу.

Середньогірна місцевість має висоти над рівнем моря 1000-2000 м, відносні перевищення $500-1000$ м і переважну крутість скатів 10-25․ Вона розчленована на добре виражені гірські масиви, гряди і ланцюги, їхні вершини і гребені звичайно мають згладжену форму.

Високогірна місцевість характеризується висотами над рівнем моря понад $2000 \mathrm{M}$ і відносними перевищеннями 1000 м і більше.
Переважна крутість скатів більше $25^{\circ}$. Високогірна місцевість розділена глибокими долинами i улоговинами на гірські хребти. Як правило, вона слабо обжита, має мало гірських проходів і рідку дорожню мережу.

Степова місцевість характеризується відсутністю деревної рослинності, сухим континентальним кліматом, чорноземними i каштановими грунтами, покритими засухостійкими i морозостійкими трав'яними рослинами, слаборозвиненою річковою мережею, іноді порізана глибокими ярами і балками.

Лісова (лісиста) місцевість являє собою територію, понад 50\% якої покрита густою деревною рослинністю (лісами). У такій місцевості прохідність залежить від наявності доріг та просік, характеру рельєфу і заболоченості грунту, густоти, товщини і породи дерев. Лісові масиви стискують маневр, обмежують огляд і дальність видимості, знижують ефективність вогню стрілецької зброї і дальність радіозв'язку. Ліси мають важливе значення не тільки як природні маски, що приховують від наземного i повітряного спостереження, а й як укриття від вражаючої дії багатьох видів зброї. До основних показників тактичних властивостей лісу, що відображається на топографічних картах, відносяться дані про його складові, густоту, стан і благоустрій.

Болотиста місцевість характеризується значно зволоженими грунтами.

Її можна розділити на торфовища і заболочені землі. Торфовища - надмірно зволожені ділянки місцевості, покриті шаром торфу глибиною не менше $30 \mathrm{~cm}$ і вологолюбною рослинністю. Заболочені землі - надмірно зволожені площі, що не мають торфу або покриті шаром торфу менше 30 см. Облаштування укриттів i виконання інших інженерних робіт сильно ускладнене близьким розташуванням грунтових вод.

Лісисто-болотиста місцевість характеризується чергуванням великих лісових ділянок 3 численними болотами, річками, струмками та озерами. Основними особливостями такої місцевості $\epsilon$ закритий характер, обумовлений наявністю лісів, і низька прохідність через вкрай рідкісну дорожню мережу, слабкі грунти і велику кількість природних перешкод.

3 урахуванням зазначеного, засоби тропосферного зв'язку доцільно застосовувати в умовах відкритої малонаселеної місцевості (малорозвинена мережа доріг, гірська та болотиста місцевість, на морському просторі, пустельні та лісові території тощо), коли для своєчасного розгортання ліній зв'язку використовувати інші види зв'язку не можливо (не доцільно).

Існуючі станції тропосферного зв'язку доцільно застосовувати в оперативній і тактичній ланках управління, у військових частинах та підрозділах різних видів (родів) військ (сил) для побудови одно- або двоінтервальних ліній зв'язку між ITB (B3) пунктів управління і системами озброєнь (об'єктами управління).

Для станцій тропосферного зв'язку та функціонування ліній тропосферного зв'язку є ряд загроз, а саме: засоби та комплекси 
радіоелектронної боротьби (придушення), засоби вогневого ураження, диверсійно-розвідувальні групи, незаконні збройні формування.

Широкий розвиток засобів та комплексів радіоелектронної боротьби, нових принципів та способів їх застосування ставить під загрозу функціонування системи зв'язку. Однією із складових радіоелектронної боротьби $є$ радіоелектронне придушення, під яким розуміється вплив навмисних завад на приймач станції тропосферного радіозв'язку 3 цілю зриву або порушення обміну інформацією.

Дана загроза обгрунтовується потужністю передавача, що полегшує виявлення джерела електромагнітного випромінювання та його аналізу.

Велика потужність передавачів $\epsilon$ однією із причин переоснащення на сучасні менш потужні станції тропосферного зв'язку 3 більшою пропускною здатністю каналів зв'язку.

Станом на початок 2021 року на озброєнні 3С України знаходяться, в основному, модернізовані мобільні цифрові тропосферні станції 3 встановленням на КУНЗі двох телескопічних антенних опор (рис. 2-3).

Пропускна спроможність тропосферних ліній зв'язку, що побудовані з використанням сучасних станцій (модернізованих і прийнятих на озброєння у ЗС України - Р-417МУ, Р-4231МУ), обмежується швидкістю 2 Мбіт/с [2]. Такої швидкості недостатньо для побудови телекомунікаційної транспортної мережі спеціального призначення, 3 урахуванням зростаючих вимог щодо забезпечення голосового та відеозв'язку, передачі даних, тощо. В сучасних цифрових тропосферних станціях іноземного виробництва застосовуються методи боротьби 3 міжсимвольною інтерференцією, адаптивну корекцію зі зворотнім зв'язком. Характерною особливістю таких станцій $\epsilon$ забезпечення роботи в режимах як тропосферного розсіювання, так і прямої видимості. Завдяки цьому закордонні спеціалісти намагаються скоротити типаж станцій, підвищують міжвидову уніфікацію засобів, що значно скорочує витрати на їх виробництво, експлуатацію і дозволяє скорочувати кількість особового складу екіпажу. Модульна конструкція станцій покращує умови ремонтопридатності та дозволяе за 1-3 хвилини 3 допомогою автоматичної сигналізації визначити несправність та замінити модуль, що вийшов 3 ладу. В деяких системах забезпечується автоматичне перемикання несправного модуля на резервний. Кожний модуль має світлоіндикацію, покази системи діагностування виведені на передню панель та вказують на їх технічний стан. В країнах НАТО [2] для вирішення проблеми підвищення розвід- та завадозахищеності радіорелейних та тропосферних засобів використовуються гостронаправлені антени, зменшуються рівні бокового та заднього випромінювань, створюються антени 3 керуємим нулем діаграми направленості, шукаються можливості керування променем випромінювання антени, а також використовуються складні сигнали, методи завадостійкого кодування, завадозахищені модеми, адаптація по потужності передавачів, впроваджується апаратура контролю та визначення завад з візуальним їх відображенням, вишукуються інженерно-технічні шляхи для створення завадозахищених багатопроменевих антенних систем. Подальше вдосконалення засобів тропосферного зв'язку, за поглядами закордонних i вітчизняних спеціалістів, направлено на прискорене впровадження цифрових методів передавання сигналів, продовження створення уніфікованих типів апаратури, що складаються 3 декількох модифікацій, використання єдиних засобів тропосферного зв'язку для військових, урядових та комерційних цілей, подальше підвищення розвід- і завадо захищеної роботи, збільшення пропускної спроможності, удосконалення роботи в режимі прямої видимості при пониженій потужності, використання крім рознесеного прийому комбінованих способів боротьби 3 багатопроменевістю, в тому числі адаптивні модеми, метод прямої корекції помилок, що дозволить підвищити ефективність використання частотного спектру. В умовах недоцільності збільшення масогабаритних показників тропосферних станції та енергії сигналу передавача, на перший план у проблемі підвищення пропускної спроможності тропосферних ліній зв'язку виходить удосконалення обробки сигналів у модемі приймача тропосферної станції. Найбільш прийнятною в цьому контексті $\epsilon$ впровадження цифрової обробки сигналів та використання цифрових антенних решіток (ЦАР). Поряд із ЦАР, пропонується використовувати механізми просторово-часової обробки (Space-Time Processing - STP) сигналів.

3 аналізу характеристик існуючих засобів тропосферного зв'язку можливо зробити висновок про те, що:

станції не призначені для роботи у режимі передачі даних в телекомунікаційних мережах, що будуються на технологіях пакетної комутації повідомлень без додаткових спряжених пристроїв; станції мають обмежені можливості щодо швидкості передавання інформації;

відсутня можливість зустрічної роботи засобів радіозв'язку старого парку та модернізованих;

низька розвід- та завадозахищеність радіоканалів;

існуючі засоби тропосферного зв'язку непристосовані для роботи в системі автоматизованого моніторингу та управління телекомунікаційними мережами;

існує обмеженість частотного діапазону при використанні засобів тропосферного зв'язку, що потребує ретельного планування радіоресурсу на кожному етапі виконання завдань;

значні масо-габаритні характеристики станцій тропосферного зв'язку i великі потужності сигналів, що випромінюються, обмежують, а іноді і взагалі виключають, їх застосування в тактичній i оперативно-тактичній ланках управління;

надійне забезпечення безпеки тропосферного зв'язку потребує розробки та реалізації алгоритму 
шифрування інформації, що циркулює в каналах управління;

застосування засобів радіозв'язку старого парку обмежене їх технічним станом та функціональними можливостями.

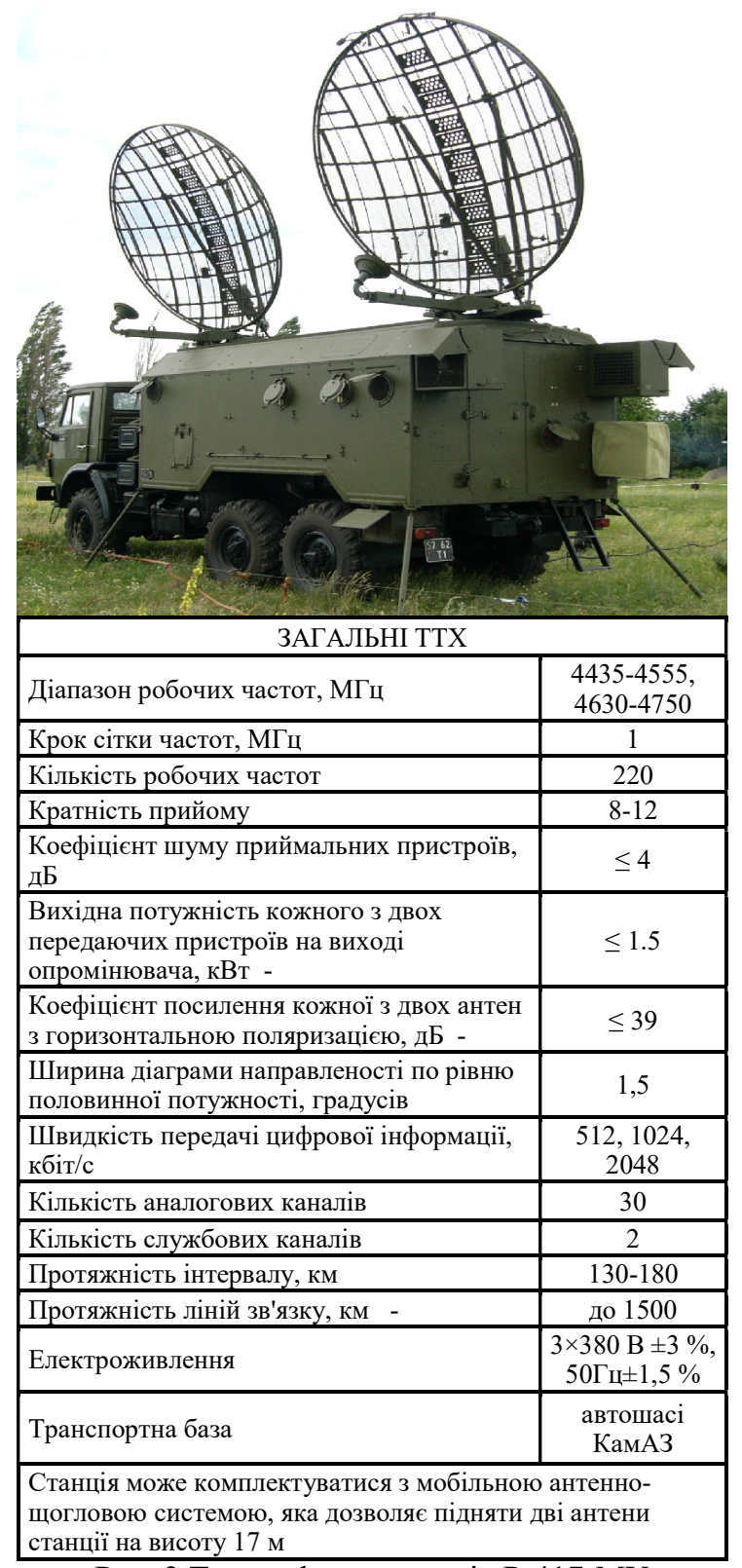

Рис. 2 Тропосферна станція Р-417-МУ

Необхідність переоснащення 3С України на сучасні засоби тропосферного зв'язку для з'єднань, частин і підрозділів ЗС України особливо актуально, що обумовлено необхідністю забезпечення можливості взаємодії в єдиному інформаційному просторі підрозділів бойового, тилового, технічного і медичного забезпечення для координації спільних дій при веденні бою, протидії терористичним актам i в умовах надзвичайних ситуацій.

Практична реалізація може бути здійснена за рахунок сталого функціонування інформаційнотелекомунікаційної системи, що буде досягнуто шляхом об'єднанням різних видів і родів зв'язку 3 метою отримання кінцевого результату.

Унікальність тропосферного зв'язку, як роду
Розв'язання зазначених проблем можливо шляхом проведення переоснащення підрозділів зв'язку сучасними засобами та комплексами тропосферного зв'язку.

системою, яомплектуватися мобільною антенно-щогловою м , працювати в режимі ретрансляції однією станцією.

Рис. 3 Тропосферна станція Р-423-1МУ

зв’язку, полягає в ряді факторів:

1. Сприятливі умови дальнього тропосферного розповсюдження радіохвиль в тропосфері на території України за рахунок відносно високої середньої температури та вологості повітря, що зумовлює відносну стабільність роботи радіоліній.

2. Відносно низький поверхневий рельєф в Україні дає додатковий внесок в покращення енергетики ліній тропосферного зв'язку, що в свою чергу збільшує стійкість роботи інформаційних напрямків.

Перевагами та недоліками тропосферного зв'язку є:

1. Розміщення антен тропосферних станцій відносно поверхні землі, на висоті 1-3 м ускладнює радіорозвідку випромінювань по 
боковим пелюсткам передавальної антени та ускладнює їх візуальне виявлення.

2. Висока ефективність ліній тропосферного зв'язку обумовлена меншою кількістю ретрансляційних станцій, по відношенню до радіорелейних ліній прямої видимості, та високою мобільністю розгортання ліній зв'язку в важкодоступних районах.

3. Значно підвищеною пропускною здатністю та якістю каналів передавання даних по відношенню до короткохвильових радіоліній

4. Лінії тропосферного зв'язку можуть ефективно використовуватися при забезпеченні зв'язку в регіонах зі слабо розвиненою телекомунікаційною інфраструктурою, в малонаселених, важкодоступних місцях, вздовж морських узбережь, через водні перешкоди, ліси, гористі території, вздовж кордонів і інших випадках.

Враховуючи переваги тропосферного зв'язку, по відношенню до інших родів зв'язку, можливо зробити висновок про доцільність економічних та воєнних аспектів переоснащення старого парку станцій тропосферного зв'язку сучасними засобами.

\section{Висновки й перспективи подальших досліджень}

3 метою набуття спроможності щодо забезпечення тропосферного зв'язку в інтересах

\section{Лimepamypa}

1. Почерняев В. Н. Состояние и направления развития мобильных цифровых тропосферных систем связи / В. Н. Почерняев, В. С. Повхлеб // Системи озброєння і військова техніка. - 2018. - № 2. - С. 51-60. 2. Масесов М. О. Перспективи застосування цифрового діаграмоутворення у станціях тропосферного зв'язку спеціального призначення / М. О. Масесов, І. Ю. Субач, Д. М. Руденко, О. В. Станович. // Збірник наукових праць ВІТІ ДУТ. - 2014. - №1. - С. 43-48. 3. Chandra Bhardwaj Sharat. Characterization and Performance Evaluation of a Typical Troposcatter Channel / Sharat Chandra Bhardwaj, Eisha Madhwal, B. S. Jassal // 2015 Second International Conference on Advances in
ЗС України військовими частинами (підрозділами) зв'язку необхідно провести наступні заходи:

Розробити (переопрацювати) нормативноправові документи щодо розвитку та функціонування тропосферного зв'язку у ЗС України.

Розробити (внести зміни) організаційно-штатну структуру підрозділів тропосферного зв'язку в межах існуючої штатної чисельності ЗС України.

Провести переоснащення підрозділів 3С України сучасними засобами тропосферного зв'язку вітчизняного та (або) закордонного виробництва.

Провести реорганізацію підрозділів сил логістики щодо обслуговування та ремонту засобів тропосферного зв'язку що знаходяться (плануються до прийняття) на озброєнні.

Виконання запропонованих заходів дозволить використовувати тропосферний зв'язок для побудови резервних тропосферних ліній зв'язку, або прямих напрямків в інтересах рухомих пунктів управління Збройних Сил України.

Подальші дослідження доцільно спрямувати на вирішення часткових наукових i науковопрактичних завдань, основними 3 яких є розробка методів та способів обробки сигналів у цифровому сегменті техніки тропосферного зв'язку, а також формування стратегії розвитку тропосферного зв’язку в інтересах Збройних Сил України.

Computing and Communication Engineering (ICACCE) 2015, IEEE, Dehradun, India. - P. 228-233. https://doi.org/10.1109/ICACCE.2015.115. 4. Li Lei. Study on the Prediction of Troposcatter Transmission Loss / Lei Li, Zhen-Sen Wu, Le-Ke Lin, Rui Zhang, Zhen-Wei Zhao // IET Microwaves, Antennas \& Propagation. - 2016. - Vol. 10 (Issue 6). - P.686-691. https://doi.org/10.1049/ietmap.2015.0293. 5. Li Chenglong. A Closed-Form Expression of Coherence Bandwidth for Troposcatter Links / Chenglong Li, Xihong Chen, Zedong Xie // IEEE Communications Letters. - 2018. - Vol. 22 (Issue 3). - P. 646-649. https://doi.org/10.1109/LCOMM.2017.2785850.

\title{
ПЕРСПЕКТИВЫ РАЗВИТИЯ ТРОПОСФЕРНОЙ СВЯЗИ В ИНФОРМАЦИОННО- ТЕЛЕКОМУТАЦИОННЫХ СИСТЕМАХ СПЕЦИАЛЬНОГО НАЗНАЧЕНИЯ
}

\author{
Евгений Александрович Степаненко (кандидат технических наук) ${ }^{1}$ \\ Вячеслав Алексеевич Думитраш ${ }^{2}$ \\ Ольга Вячеславовна Думитраш ${ }^{3}$ \\ Виталий Валерьевич Кокошинский ${ }^{2}$ \\ ${ }^{1}$ Воинская часть А0106, Киев, Украина \\ ${ }^{2}$ Военный институт телекоммуникаций та информатизации имени Героев Крут, Киев, Украина \\ ${ }^{3}$ Воинская часть А0415, Семиполки, Украина
}

Современные военные конфликты изменили общий подход к ведению боевых действий. Ранее войны развивались путем нарастания масштабности (массовости) при непосредственном контакте войск (сил), то современные войны ведутся по принципу уменьшения человеческого ресурса при увеличении использования высокочнтеллектуального оружси на значительных расстояниях. На сегодняшний день широкое применение высокоточного оружия, средств огневого поражения в сочетании со средствами разведки, диверсионно-разведывательных групп, незаконных вооруженных формирований, средств радиоэлектронного подавления существенно влияет на функционирование системы военной связи.

Данная тенденция в будущеем будет только усиливаться, что создает угрозы функционирования системы управления.

Modern Information Technologies in the Sphere of Security and Defence $\mathcal{N} N$ o 3(42)/2021 ISSN2311-7249(Print)/ISSN2410-7336(OnGine) 
В войне будущего, каждое государство ставит своей задачей адекватно и своевременно выявить ключевые риски, направление технологического развития и понять, как оно может повлиять на потеничиал возможного будущего военного конфликта.

В обозримом будущем основу перспективной информационно-телекоммуникационной системь ВС Украины должна составлять объединенная автоматизированная ичифровая система связи, которая должна включать космический, воздушный, наземный (полевой и стационарный) и морской компонент, автоматизированную систему управления связью и систему информационной безопасности и должна способствовать более тесному сближению (взаимной интеграции) систем управления войсками и оружием в единую информационно-разведывательно-огневую (ударную) пространственно распределенную систему, ключевыми элементами которой являются разведывательно-ударные комплексы.

В этой связи возникла необходимость корректировки подходов к определению основньхх направлений развития средств и комплексов тропосферной связи как составляющей информаџионнотелекоммуникационной системы ВС Украиньл.

В статье изложень предложения относительно перспектив развития средств тропосферной связи в интересах Вооруженных Сил Украиньл.

Ключевые слова: тропосферная связь; электромагнитная совместимость; физикогеографические условия.

\title{
PROSPECTS FOR THE DEVELOPMENT OF TROPOSPHERIC COMMUNICATION IN INFORMATION AND TELECOMMUNICATION SYSTEMS FOR SPECIAL PURPOSE
}

\author{
Yevhen Stepanenko (Candidate of technical sciences) ${ }^{1}$ \\ Viacheslav Dumitrash ${ }^{2}$ \\ Olha Dumitrash ${ }^{3}$ \\ Vitalii Kokoshynskyi ${ }^{2}$

\section{Military unit A0106, Kyiv, Ukraine \\ 2 Military Institute of Telecommunications and Information Technologies named after Heroes of Kruty, Ukraine 3 Military unit A0415, Semipolki, Ukraine}

Modern military conflicts have changed the general approach to the conduct of hostilities. Previously, wars developed by increasing the scale (mass character) with direct contact of troops (forces), but modern wars are waged on the principle of a decrease in human resources with an increase in the use of highly intelligent weapons at significant distances. Today, the widespread use of high-precision weapons, means of fire destruction in combination with reconnaissance means, sabotage and reconnaissance groups, illegal armed formations, means of electronic suppression significantly affects the functioning of the military communications system.

This trend will only intensify in the future, which creates threats to the functioning of the control system.

In the war of the future, each state sets its task to adequately and timely identify key risks, the direction of technological development and understand how it can affect the potential of a possible future military conflict.

In the foreseeable future, the basis of the promising information and telecommunications system of the Armed Forces of Ukraine should be a united automated digital communication system, which should include a space, air, ground (field and stationary) and marine component, an automated communications control system and an information security system and should contribute to closer convergence (mutual integration) of command and control systems of troops and weapons into a single information-reconnaissance-fire (strike) spatially distributed system, the key elements of which are reconnaissance-strike complexes.

In this regard, it became necessary to adjust the approaches to determining the main directions of development of means and complexes of tropospheric communication as a component of the information and telecommunication system of the Armed Forces of Ukraine.

The article contains proposals regarding the prospects for the development of tropospheric radio communications in the interests of the Armed Forces of Ukraine. conditions.

Keywords: tropospheric communications; electromagnetic compatibility; physical and geographical

\section{References}

1. Pochernyaev V.N. State and development directions of mobile digital tropospheric communication systems / V.N. Pochernyaev, V.S. Povkhleb // Weapons systems and military equipment. - 2018. - № 2. - P. 51-60. 2. Masesov M.O. Prospects for the use of digital diagram formation in tropospheric communication stations of special purpose // Collection of scientific works VITI DUT. - 2014. - №1. - P. 43-48. 3. Chandra Bhardwaj Sharat. Characterization and Performance Evaluation of a Typical Troposcatter Channel / Sharat Chandra Bhardwaj, Eisha Madhwal, B. S. Jassal // 2015 Second International Conference on Advances in Computing and Communication
Engineering (ICACCE) - 2015, IEEE, Dehradun, India. - P. 228-233. https://doi.org/10.1109/ICACCE.2015.115.

4. Li Lei. Study on the Prediction of Troposcatter Transmission Loss / Lei Li, Zhen-Sen Wu, Le-Ke Lin, Rui Zhang, Zhen-Wei Zhao // IET Microwaves, Antennas \& Propagation. - 2016. - Vol. 10 (Issue 6). - P.686-691. https://doi.org/10.1049/iet-map.2015.0293. . Li Chenglong. A Closed-Form Expression of Coherence Bandwidth for Troposcatter Links / Chenglong Li, Xihong Chen, Zedong Xie // IEEE Communications Letters. - 2018. - Vol. 22 $\begin{array}{lllll}\text { (Issue } & 3 \text { ). } & - & \text { P. } & \text { 646-649. }\end{array}$ https://doi.org/10.1109/LCOMM.2017.2785850. 